\title{
Buccal midazolam for pediatric convulsive seizures: efficacy, safety, and patient acceptability
}

\author{
This article was published in the following Dove Press journal: \\ Patient Preference and Adherence \\ 9 January 2013 \\ Number of times this article has been viewed
}

\section{Mark Anderson \\ Great North Children's Hospital, Newcastle upon Tyne Hospitals NHS Foundation Trust, Newcastle upon Tyne, United Kingdom}

\begin{abstract}
Prolonged seizures and status epilepticus are a common acute neurological presentation in pediatric practice. As a result, there is a need for effective and safe medications that can be delivered to convulsing children to effect rapid seizure termination both in hospital and community settings. The challenges of achieving intravenous access, particularly in young children, mandate alternative routes of administration for these drugs. Over the last ten years, midazolam delivered via the buccal mucosa has been demonstrated to be efficacious, safe, and acceptable to children and their caregivers, and a formulation has recently been licensed for use in Europe. The aim of this article is to review the clinical pharmacology with respect to these issues.
\end{abstract}

Keywords: pediatrics, neurology, pharmacology, buccal midazolam

\section{Introduction}

Prolonged seizures are a common problem in both adult and pediatric practice. While the classical definition of status epilepticus encompasses seizure activity lasting 30 minutes or more, or a series of seizures without recovery of consciousness between them, it is widely agreed that treatment to effect termination should not be delayed. The longer a seizure endures, the more likely the development of pharmacoresistance, ${ }^{1}$ and animal studies would suggest a greater likelihood of neuronal damage. ${ }^{2}$ As a result, an operational definition of a seizure or intermittent seizures without full recovery of consciousness lasting more than 5 minutes is used as a guide for intervention. ${ }^{3}$

Population-based studies of the incidence of status epilepticus in the developed world estimate an incidence of 10-20 per 100,000 individuals per year in the adult population, with the incidence rising with age. ${ }^{4}$ Only two studies have attempted to determine the incidence in children, with results of 10.9 cases per 100,000 per year in Switzerland, ${ }^{5}$ and more recently an estimate of $17-23$ cases per 100,000 per year in North London, UK. ${ }^{6}$ This latter study showed an age predominance in the first four years of life, with a recurrence rate of $17 \%$ in one year. These studies of status epilepticus used the classical definition and therefore underestimate the true incidence and burden of prolonged seizures requiring treatment as delineated above. In addition, the incidence is likely to be significantly higher in areas where malaria is endemic, with cerebral malaria being a common cause of prolonged seizures. ${ }^{7}$

The association of seizure duration with increased pharmacoresistance to termination underlines the need for effective therapy to be given early in the time course. This mandates an agent that can be safely administered outside the health care environment
Correspondence: Mark Anderson Great North Children's Hospital, Newcastle upon Tyne Hospitals NHS Foundation Trust, Queen Victoria Road, Newcastle upon Tyne, NE4 ILP, United Kingdom

Tel +44 I9l 2823849

Email mark.anderson7@nuth.nhs.uk 
by caregivers or primary responders. The ideal drug for such a purpose would have the following characteristics:

- rapid onset of action

- broad spectrum of efficacy, ie, not restricted to a particular seizure type or underlying cause

- prolonged duration of action

- minimal adverse effects

- simple and socially acceptable administration route for both patient and caregiver

- easy storage and portability.

Benzodiazepines have been used for the management of acute seizures and epilepsy since the 1960s and are, at present, the drugs of first choice for status epilepticus and prolonged seizures in both adults and children. ${ }^{8}$ The benzodiazepines share a common set of neuropharmacological effects, including anxiolysis, sedation, muscle relaxation, and anticonvulsant action. The differing affinity of each of the benzodiazepines for their receptor subtypes account for the extent to which they exert each of these effects. In general, the benzodiazepines, diazepam, lorazepam, and midazolam, have been the most studied and are therefore preferred for the acute management of seizures.

For a significant period of time, diazepam, administered rectally, has been the treatment of choice for effecting the cessation of prolonged or serial seizures in the community. However, the requirement for rectal delivery represents a significant barrier to its use. From the patient's perspective, it adds the need for exposure of intimate anatomy to the potential embarrassment of suffering a seizure. There is a similar concern from a caregiver's point of view allied to the fact that the route is not particularly accessible, particularly for larger adults, leading to a reluctance to give the drug. In addition, people administering rectal diazepam may be concerned that they are placing themselves at risk of allegations of sexual abuse..$^{9}$ As a result, over the past 10 years, midazolam delivered into the buccal cavity has been growing in popularity and is now the preferred drug for this indication in the UK. ${ }^{8}$ The aim of this article is to review the pharmacology, utility, and acceptability of buccal midazolam in relation to its use for acute seizure control.

\section{Buccal route}

Systemic delivery of drugs via the buccal or sublingual mucosa in emergency situations is not a recent development. The effect of sublingual administration of nitroglycerin for the relief of cardiac chest pain was described as early as $1957 .{ }^{10}$ The route has subsequently merited particular study due to its potential for high patient compliance and unique physiological features.
The buccal mucosa has a large surface area (estimated $50 \mathrm{~cm}^{2}$ ) and a relatively porous epithelial membrane, even compared with other mucosal surfaces of the mouth. It is highly vascularized and any drug diffusing across the oral mucosal membranes has direct access to the systemic circulation, bypassing the portal circulation and hence, first-pass metabolism by the liver. In addition, the high rate of blood flow does not present a limiting step to absorption. The buccal mucosa has a lower degree of enzyme expression and activity than the gastrointestinal tract, leading to less drug degradation prior to absorption; ${ }^{11}$ the degree of metabolism will, of course, also depend upon the individual drug. Most studies of absorption across the buccal membrane demonstrate that the principal mechanism is passive diffusion across lipid membranes. ${ }^{12}$ Table 1 lists some of the potential advantages offered by the buccal route which demonstrate the utility of this route in the emergency situation.

The intranasal route has also been studied in the context of emergency drug administration. It is as accessible as the buccal route and its epithelial membrane is also relatively porous and well vascularized. However, it is limited in that the nasal cavity is of relatively small capacity and is easily flooded by small volumes of drug (approximately $200 \mu \mathrm{L}$ per adult nostril), leading to loss of active drug to respiration. In addition, in young children, the route is often congested by mucus, which may affect absorption. ${ }^{9}$

\section{Basic pharmacology}

Midazolam exerts its action by interacting reversibly with the benzodiazepine binding site of the $\gamma$-aminobutyric acid receptor subtype A $\left(\mathrm{GABA}_{\mathrm{A}}\right)$. These are pentameric transmembrane ligand-gated chloride ion channels distributed throughout the neuronal membranes of the central nervous system. Binding of GABA to the receptor results in an inhibitory effect on neurotransmitter release, and when activated by GABA, the $\mathrm{GABA}_{\mathrm{A}}$ receptor allows influx of chloride ions, causing hyperpolarization of the neuron membrane.

Benzodiazepines do not bind to the same site as GABA, but to a distinct alternative site. This results in positive allosteric

Table I Potential advantages of the buccal route of drug delivery

\begin{tabular}{ll}
\hline Advantage & Effect \\
\hline Rapid absorption & Fast onset of therapeutic effect \\
Circumvention of portal circulation & $\begin{array}{l}\text { No first-pass hepatic } \\
\text { metabolism }\end{array}$ \\
Circumvention of intestinal absorption & $\begin{array}{l}\text { No gastrointestinal enzyme } \\
\text { degradation }\end{array}$ \\
Noninvasive & $\begin{array}{l}\text { Reduced risk of infection } \\
\text { Easily accessible and socially acceptable }\end{array}$ \\
\hline
\end{tabular}


modulation of the receptor, resulting in an increased affinity for GABA, leading to increased frequency of opening of the chloride channel and thereby an enhanced inhibitory action. This explains the anticonvulsant action of benzodiazepines.

Midazolam is metabolized primarily by the cytochrome P450 (CYP) 3A4 isoenzyme. This enzyme is expressed primarily in the liver, but is also active in the intestinal mucosa. As a result, the oral bioavailability of midazolam is only approximately $40 \%$. The unconjugated metabolite, $\alpha$-hydroxymidazolam, is also pharmacologically active and contributes about $10 \%$ of the pharmacological effect of midazolam. The glucuroconjugated $\alpha$-hydroxymidazolam is excreted in urine, with a terminal elimination half-life of about one hour. Due to the almost exclusive metabolism mediated by the CYP3A4 isoenzyme, coadministration of CYP3A4 inhibitors and inducers may result in pharmacokinetic interactions. CYP3A4 is only expressed at low levels in the liver in the neonatal period, increasing to adult levels over the first year of life. Consequently, young infants may experience more prolonged effects, both desirable and undesirable, and repeated dosing may lead to accumulation. ${ }^{3}$

The characteristic undesirable effects of benzodiazepines are reported also for midazolam. Sedation, amnesia, impaired attention, and impaired muscular function may adversely affect the ability to drive or use machines. Paradoxical reaction such as agitation, involuntary movements, hyperactivity, hostility, rage reactions, aggressiveness, excitement, and assault have been reported. These reactions occur mainly with high doses and/or when the injection is given rapidly. The highest risk for paradoxical reaction has been reported for children and elderly patients, as well as patients with actual or amnestic psychiatric diseases and patients with alcohol addiction. Furthermore paradoxical reaction is often related to high midazolam doses. ${ }^{13}$

Midazolam is unique among the benzodiazepines in that its lipophilicity and hydrophilicity is pH-dependent (Figure 1). The alkaline nitrogen in position 2 of the imidazobenzodiazepine ring system enables midazolam to form water-soluble salts with acids. Under acidic conditions, midazolam is present as an equilibrium mixture of the closed-ring form and an open-ring structure, formed by the acid catalyzed ring opening of the 4,5-double bond of the diazepine ring. Under physiologic conditions $\left(\mathrm{pH} 7.5,37^{\circ} \mathrm{C}\right)$, the openring form reverts to the physiologically active, lipophilic, closed-ring form. ${ }^{14}$ These physicochemical properties provide significant flexibility for the production of a formulation of midazolam suitable for transmucosal administration when compared with some of the other benzodiazepines. The basic pharmacokinetic parameters of midazolam are summarized in Table 2, and in comparison with diazepam and lorazepam.

\section{Clinical pharmacology}

Midazolam, lorazepam, and diazepam have all been studied to a greater or lesser extent following buccal administration, although midazolam more extensively so, particularly in relation to seizure termination.

The pharmacokinetic studies of midazolam and lorazepam (included for comparison) following buccal administration are summarized in Table 3. Diazepam has not been studied in this way. These studies demonstrate that the time taken to reach peak plasma concentrations is significantly lower for midazolam compared with lorazepam. This indicates that it is more likely to achieve therapeutic plasma concentrations, and buccal midazolam is thus more useful than buccal lorazepam
A

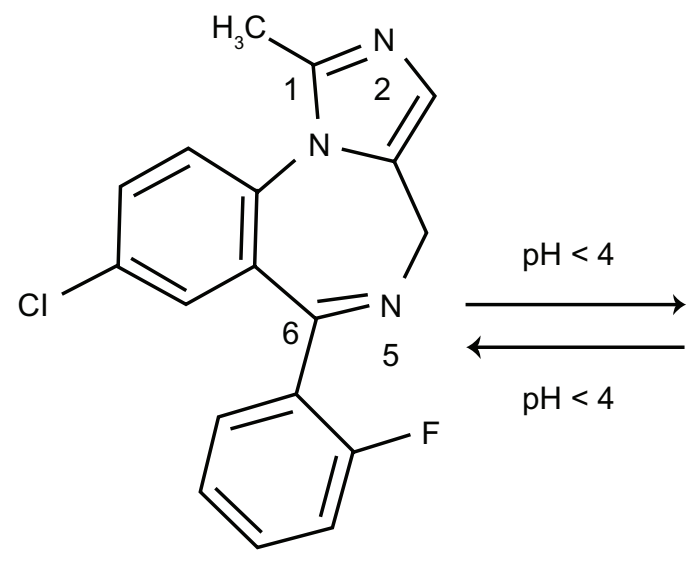

B

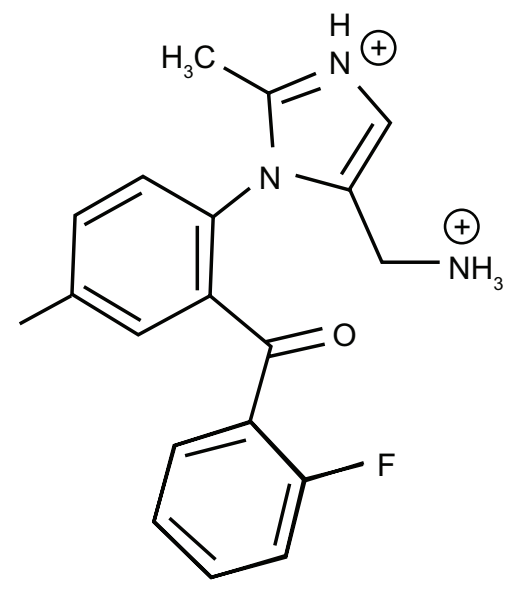

Figure I PH-dependent lipo-and hydrophilicity of midazolam. 
Table 2 Summary of the pharmacokinetic parameters of the main benzodiazepines used to effect acute seizure termination ${ }^{15}$

\begin{tabular}{llll}
\hline & Midazolam & Lorazepam & Diazepam \\
\hline Oral bioavailability (\%) & 40 & 99 & 100 \\
Volume of distribution (L/kg) & $0.8-1.7$ & $0.8-1.3$ & $0.7-1.7$ \\
Metabolic pathway & Hydroxylation & Glucuronidation & Demethylation, hydroxylation, glucuronidation \\
Elimination half-life of parent drug (hours) & $1.7-3.5$ & $8-25$ & $20-100$ \\
Elimination half-life of major active metabolite (hours) & 1.1 & $\mathrm{NA}$ & $30-200$ \\
\hline
\end{tabular}

Abbreviation: NA, not applicable.

Table 3 Pharmacokinetic studies of buccal midazolam and lorazepam

\begin{tabular}{|c|c|c|c|c|c|c|}
\hline Author & Drug & Dose (mg) & Subjects & $\mathbf{T}_{\max }$ (minutes) & $C_{\max }(\mathrm{ng} / \mathrm{mL})$ & Comments \\
\hline Scott et al ${ }^{16}$ & Midazolam & 10 & 10 healthy adults & $46 \pm 28$ & $32.7 \pm 3.2$ & \\
\hline Schwagmeier et al ${ }^{17}$ & Midazolam & 5 & 8 healthy adults & $30(15-90)$ & $55.9(35.6-77.9)$ & $\begin{array}{l}\text { Bioavailability } \\
74.5 \%\end{array}$ \\
\hline Muchohi et al ${ }^{18}$ & Midazolam & $0.3 \mathrm{mg} / \mathrm{kg}$ & $\begin{array}{l}8 \text { children } \\
\text { with malaria }\end{array}$ & $10(5-40)$ & $186(64-394)$ & $\begin{array}{l}\text { Bioavailability } \\
87 \%\end{array}$ \\
\hline Greenblatt et a $\left.\right|^{19}$ & Lorazepam & $2 \mathrm{mg}$ & I0 healthy adults & 135 & 20.7 & Sublingual administration \\
\hline Anderson et $\mathrm{al}^{20}$ & Lorazepam & $2 \mathrm{mg}$ & 12 healthy adults & $160.9 \pm 46.9$ & $14.4(3.3)$ & \\
\hline
\end{tabular}

Abbreviations: $T_{\max }$ time to maximum plasma concentration (mean \pm standard deviation, range); $C_{\max }$, maximum plasma concentration (mean \pm standard deviation, range); IV, intravenous.

Table 4 Summary of comparative trials of buccal midazolam

\begin{tabular}{|c|c|c|c|c|}
\hline Author & Patient group & $\begin{array}{l}\text { Dose of buccal } \\
\text { midazolam }\end{array}$ & Comparator & Outcome measures \\
\hline Scott et $\mathrm{al}^{9}$ & $\begin{array}{l}\text { I } 8 \text { children and young people } \\
\text { in a UK residential center for severe } \\
\text { epilepsy ( } 79 \text { episodes of seizure) }\end{array}$ & $10 \mathrm{mg}$ & Rectal diazepam 10 mg & $\begin{array}{l}\text { Seizure termination within } \\
10 \text { minutes of administration }\end{array}$ \\
\hline $\begin{array}{l}\text { Mclntyre } \\
\text { et } \mathrm{al}^{21}\end{array}$ & $\begin{array}{l}\text { I77 children and young people } \\
\text { (aged } 6 \text { months to } 16 \text { years) } \\
\text { presenting to UK emergency } \\
\text { departments ( } 219 \text { episodes } \\
\text { of seizure) }\end{array}$ & $\begin{array}{l}2.5 \mathrm{mg} \text { (age 6-12 months) } \\
5 \mathrm{mg} \text { (age I-4 years) } \\
7.5 \mathrm{mg} \text { (age } 5-9 \text { years) } \\
10 \mathrm{mg} \text { (age } 10 \text { years }+ \text { ) }\end{array}$ & $\begin{array}{l}\text { Rectal diazepam, same } \\
\text { dose as midazolam }\end{array}$ & $\begin{array}{l}\text { Seizure termination within } \\
10 \text { minutes of administration }\end{array}$ \\
\hline $\begin{array}{l}\text { Baysun } \\
\text { et al }{ }^{22}\end{array}$ & $\begin{array}{l}43 \text { children (aged }<12 \text { years) } \\
\text { presenting to a children's } \\
\text { emergency department in Turkey }\end{array}$ & $0.25 \mathrm{mg} / \mathrm{kg}$ & $\begin{array}{l}\text { Rectal diazepam } \\
0.5 \mathrm{mg} / \mathrm{kg} \text { (age }<5 \text { years) } \\
0.3 \mathrm{mg} / \mathrm{kg} \text { (age }>5 \text { years) }\end{array}$ & $\begin{array}{l}\text { Seizure termination within } \\
10 \text { minutes of administration }\end{array}$ \\
\hline $\begin{array}{l}\text { Mpimbaza } \\
\text { et } \mathrm{al}^{23}\end{array}$ & $\begin{array}{l}330 \text { children (aged } 3 \text { months } \\
\text { to } 12 \text { years) presenting to } \\
\text { an emergency department } \\
\text { in Uganda }\end{array}$ & $\begin{array}{l}2.5 \mathrm{mg} \text { (age } 6-12 \text { months) } \\
5 \mathrm{mg} \text { (age I-4 years) } \\
7.5 \mathrm{mg} \text { (age } 5-9 \text { years) } \\
10 \mathrm{mg} \text { (age } 10 \text { years+) }\end{array}$ & $\begin{array}{l}\text { Rectal diazepam, same } \\
\text { dose as midazolam }\end{array}$ & $\begin{array}{l}\text { Seizure termination within } \\
10 \text { minutes of administration }\end{array}$ \\
\hline $\begin{array}{l}\text { Talukdar and } \\
\text { Chakrabarty }\end{array}$ & $\begin{array}{l}\text { I } 20 \text { children (aged }<12 \text { years) } \\
\text { presenting to an emergency } \\
\text { department in India }\end{array}$ & $0.2 \mathrm{mg} / \mathrm{kg}$ & $\begin{array}{l}\text { Intravenous diazepam } \\
0.3 \mathrm{mg} / \mathrm{kg}\end{array}$ & $\begin{array}{l}\text { Seizure termination within } \\
5 \text { minutes of administration }\end{array}$ \\
\hline $\begin{array}{l}\text { Ashrafi } \\
\text { et } \mathrm{al}^{25}\end{array}$ & $\begin{array}{l}98 \text { children (aged } 3 \text { months to } \\
12 \text { years) presenting to the } \\
\text { emergency departments } \\
\text { of two Iranian hospitals }\end{array}$ & $0.3-0.5 \mathrm{mg} / \mathrm{kg}$ & $\begin{array}{l}\text { Rectal diazepam } \\
0.5 \mathrm{mg} \cdot \mathrm{kg}\end{array}$ & $\begin{array}{l}\text { Seizure termination within } \\
5 \text { minutes of administration } \\
\text { Buccal midazolam as effective } \\
\text { as rectal diazepam }\end{array}$ \\
\hline $\begin{array}{l}\text { Nakken and } \\
\text { Lossius }^{26}\end{array}$ & $\begin{array}{l}22 \text { adults in a Norwegian } \\
\text { residential center for severe } \\
\text { epilepsy ( } 80 \text { episodes of seizure) }\end{array}$ & $10-20 \mathrm{mg}$ & $\begin{array}{l}\text { Rectal diazepam } \\
10-30 \mathrm{mg}\end{array}$ & $\begin{array}{l}\text { Seizure termination within } \\
10 \text { minutes of administration }\end{array}$ \\
\hline
\end{tabular}


for the treatment of acute seizures where rapid termination is desirable. However, extension of these data to the clinical situation is fraught. A minimum effective plasma concentration at which each of the benzodiazepines effects its anticonvulsant action has not been defined. This is likely to be due to the significant variation between individuals and cause of seizure.

\section{Efficacy studies}

Virtually all of the prospective randomized and quasi-randomized controlled trial data relating to treatment of prolonged seizures with buccal midazolam have been collected from studies of children and adolescents. These data are summarized in Table 4. Five studies compared its efficacy against that of rectal diazepam. In all of these, buccal midazolam was found to be as effective or more effective. In one study, ${ }^{24}$ efficacy was compared with intravenous diazepam, and observed that time to seizure termination following drug administration was shorter with intravenous diazepam, but that once the time to achieve intravenous access was accounted for, the mean time elapsed between noticing seizure activity and its control was significantly less for buccal midazolam. Therefore, there is a significant body of evidence supporting buccal midazolam as first-line therapy for prolonged seizures, where intravenous drug administration is not possible or practical.

\section{Safety}

The major safety concern regarding administration of benzodiazepines to children experiencing a prolonged seizure is the risk of respiratory depression, especially if it should occur outside of hospital. Respiratory depression was reported in two of the comparative trials listed in Table 4, with an incidence of $0.6 \%-5 \%$. This was not increased compared with that seen in the diazepam-treated groups.

As a result, there have been suggestions that a test dose of buccal midazolam should be given to children in hospital prior to its use in the community. ${ }^{27}$ However, a dose given to a conscious, nonconvulsing child does not mimic its use during a seizure, and most clinicians do not follow this practice. ${ }^{28}$

\begin{tabular}{|c|c|c|}
\hline Key findings & Trial conclusion & Comments \\
\hline $\begin{array}{l}\text { Buccal midazolam: } 75 \% \text { of seizures responded ( } 30 \text { of } 40 \text { episodes) } \\
\text { Rectal diazepam: } 59 \% \text { of seizures responded ( } 23 \text { of } 39 \text { episodes, } \\
P=0.016)\end{array}$ & $\begin{array}{l}\text { Buccal midazolam is as effective } \\
\text { as rectal diazepam }\end{array}$ & $\begin{array}{l}\text { Small sample size } \\
\text { Two patients accounted for nearly } 50 \% \\
\text { of the seizure episodes } \\
\text { No adverse cardiorespiratory effects } \\
\text { were recorded }\end{array}$ \\
\hline $\begin{array}{l}\text { Buccal midazolam: } 56 \% \text { of seizures responded ( } 61 \text { out of } \\
\text { I09 episodes) } \\
\text { Rectal diazepam: } 27 \% \text { of seizures responded ( } 30 \text { out of } \\
\text { I } 10 \text { episodes) } \\
P<0.00 \text { I }\end{array}$ & $\begin{array}{l}\text { Buccal midazolam more effective } \\
\text { than rectal diazepam }\end{array}$ & $\begin{array}{l}5 \text { children in buccal midazolam arm } \\
\text { and } 7 \text { children in rectal diazepam arm } \\
\text { experienced respiratory depression }\end{array}$ \\
\hline $\begin{array}{l}\text { Buccal midazolam: } 78 \% \text { of seizures responded ( } 18 \text { out of } \\
23 \text { patients) } \\
\text { Rectal diazepam: } 85 \% \text { of seizures responded ( } 17 \text { out of } \\
20 \text { patients, } P>0.05 \text { ) }\end{array}$ & $\begin{array}{l}\text { Buccal midazolam as effective } \\
\text { as rectal diazepam }\end{array}$ & $\begin{array}{l}\text { Small sample size } \\
\text { I child in rectal diazepam group } \\
\text { experienced respiratory depression }\end{array}$ \\
\hline $\begin{array}{l}\text { Buccal midazolam: } 69.7 \% \text { of seizures responded ( } 115 \text { of } \\
165 \text { patients) }\end{array}$ & $\begin{array}{l}\text { Buccal midazolam more effective } \\
\text { than rectal diazepam }\end{array}$ & $\begin{array}{l}\text { Malaria the most common cause for } \\
\text { seizures }(67.3 \% \text { of patients })\end{array}$ \\
\hline $\begin{array}{l}\text { Rectal diazepam: } 57 \% \text { of seizures responded ( } 94 \text { of } \\
165 \text { patients, } P=0.016)\end{array}$ & & $\begin{array}{l}2 \text { patients in each group experienced } \\
\text { respiratory depression }\end{array}$ \\
\hline $\begin{array}{l}\text { Buccal midazolam: } 85 \% \text { of seizures responded ( } 5 \text { I of } 60 \text { patients); } \\
\text { Intravenous diazepam: } 93.3 \% \text { of seizures responded ( } 56 \text { of } \\
60 \text { patients, } P=0.142 \text { ) }\end{array}$ & $\begin{array}{l}\text { Buccal midazolam as effective } \\
\text { as intravenous diazepam }\end{array}$ & $\begin{array}{l}\text { No adverse cardiorespiratory effects } \\
\text { recorded }\end{array}$ \\
\hline $\begin{array}{l}\text { Buccal midazolam: } 100 \% \text { of seizures responded ( } 49 \text { out of } \\
49 \text { patients) }\end{array}$ & $\begin{array}{l}\text { Buccal midazolam as effective } \\
\text { as rectal diazepam }\end{array}$ & $\begin{array}{l}\text { No adverse cardiorespiratory effects } \\
\text { recorded }\end{array}$ \\
\hline $\begin{array}{l}\text { Rectal diazepam } 82 \% \text { of seizures responded ( } 40 \text { of } 49 \text { patients, } \\
P<0.001)\end{array}$ & & \\
\hline $\begin{array}{l}\text { Buccal midazolam: } 74.4 \% \text { of seizures responded ( } 32 \text { of } \\
43 \text { episodes) } \\
\text { Rectal diazepam: } 83.3 \% \text { of seizures responded ( } 30 \text { of } \\
37 \text { episodes, } P \text { not significant) }\end{array}$ & $\begin{array}{l}\text { Buccal midazolam as effective } \\
\text { as rectal diazepam }\end{array}$ & $\begin{array}{l}\text { Small sample size } \\
\text { No adverse cardiorespiratory effects } \\
\text { recorded }\end{array}$ \\
\hline
\end{tabular}


Open-label prospective and retrospective studies and case reports are also a valuable source of signals of potential adverse effects. Both Kutlu et $\mathrm{a}^{29}$ and Melendez et a ${ }^{30}$ reported no adverse cardiorespiratory effects in their series of patients. There is a single case report of an episode of hypotension following administration of buccal midazolam. ${ }^{31}$ An online report of a search of the UK National Health Service National Reporting and Learning System following a signal generated by a event involving respiratory depression in the community attributed to buccal midazolam administration revealed 132 reported medication incidents. ${ }^{32}$ Three of these were associated with severe harm and five with moderate harm. Little further information is provided, but it would appear that these events were associated with "wrong dose errors", eg, ten-fold overdosing. As a result, although difficult to quantify accurately, it would appear that the risk of cardiorespiratory compromise as a result of administration of buccal midazolam is acceptably low.

There have been some theoretical concerns regarding the administration of a medication into the mouth of an actively convulsing child with respect to the risk of aspiration. However, the volumes of drug are very small and are likely to be exceeded significantly by the excess saliva produced during a seizure. In practice, these concerns have not materialized as safety issues.

\section{Patient and caregiver acceptability}

There has been little formal study of the acceptability of buccal midazolam to both patients and their caregivers. It would seem self-apparent that the buccal route is much preferred over the rectal route, for reasons of ease of administration and obviation of the need to expose intimate body areas. Data from comparative trials are limited but indicate that, where measured, the time required for buccal drug administration is significantly less than for the rectal or intravenous routes. In addition, Ashrafi et a ${ }^{25}$ reported that $94 \%$ of parents whose children were treated with buccal midazolam were satisfied with the care they had received compared with only $14 \%$ of those parents whose children had been treated with rectal diazepam. Nakken and Lossius ${ }^{26}$ reported that all nursing staff involved in their trial preferred administering buccal midazolam to rectal diazepam.

A telephone survey of the parents of 53 children who had been prescribed buccal/nasal midazolam was conducted in 2004. ${ }^{33}$ Eighty-three percent of families reported it to be effective and easy to use. In addition, of those families who had previously used rectal diazepam, $83 \%$ preferred midazolam.
Table 5 Recommended doses for buccal midazolam ${ }^{35}$

\begin{tabular}{ll}
\hline Age range & Dose \\
\hline 3 months up to one year & $2.5 \mathrm{mg}$ \\
One year up to 5 years & $5 \mathrm{mg}$ \\
5 years up to 10 years & $7.5 \mathrm{mg}$ \\
10 years up to 18 years & $10 \mathrm{mg}$ \\
\hline
\end{tabular}

\section{Licensed status and dose recommendations}

Until 2012, midazolam was administered buccally for prolonged seizures on an unlicensed basis. The initial randomized trials $^{9,21,22}$ used the intravenous preparation of midazolam. However, solutions of midazolam specifically for buccal use were subsequently developed, although on an unlicensed basis. In particular, Epistatus ${ }^{\circledR}$ (Special Products Ltd, Weybridge, UK) was used in two trials. ${ }^{25,26}$ The other trials did not stipulate the formulation of midazolam used. In 2012, Buccolam ${ }^{\circledR}$ (Viropharma, Downingtown, PA) was granted a license by the European Medicines Agency for the treatment of prolonged, acute, convulsive seizures in infants, toddlers, children, and adolescents (from 3 months to $<18$ years). ${ }^{34}$ Buccolam has the same formulation as the intravenous preparation but is presented in prefilled syringes for ease of administration. In the US, buccal midazolam does not appear to be used for this indication. The only medication approved by the US Food and Drug Administration for nonintravenous treatment of prolonged seizures is rectal diazepam.

The original dose of buccal midazolam for treating prolonged seizures was $0.3 \mathrm{mg} / \mathrm{kg}$, up to a maximum of $10 \mathrm{mg}$. However, this has recently been changed to age-defined recommendations, and details of these doses are summarized in Table 5. These are the licensed doses for Buccolam.

\section{Conclusion}

There is now a wealth of evidence demonstrating the efficacy of buccal midazolam for the termination of acute prolonged seizures in children. This has been recognized by its inclusion in many national guidelines, and interestingly its extension into adult practice; perhaps one of the few occasions in drug development where children have led the way. As a result, a licensed product is now available in Europe (Buccolam). This product is in receipt of the first Paediatric Use Marketing Authorisation to be granted by the European Medicines Agency.

Work carried out on acceptability to patients supports the prima facie view that administration of a drug into the mouth is preferable to administration into the rectal cavity. The development of therapies for use by parents, caregivers, and paramedics to terminate seizures in the community has 
significantly improved the quality of life of families and individuals. Buccal midazolam for prolonged seizures is both effective and safe. The buccal route avoids the social stigma of rectal administration, particularly in older children and adults, and it is appropriate that buccal midazolam should be considered the treatment of choice.

\section{Disclosure}

The author reports no conflicts of interest in this work.

\section{References}

1. Chin RF, Neville BG, Peckham C, Wade A, Bedford H, Scott RC Treatment of community-onset, childhood convulsive status epilepticus: a prospective, population-based study. Lancet Neurol. 2008;7 696-703.

2. Scantlebury MH, Heida JG, Hasson HJ, et al. Age-dependent consequences of status epilepticus: animal models. Epilepsia. 2007: 48 Suppl 2:75-82.

3. Anderson M. Benzodiazepines for prolonged seizures. Arch Dis Child Educ Pract Ed. 2010;95:183-189.

4. Chin RFM, Neville BGR, Scott RC. A systematic review of the epidemiology of status epilepticus. Eur J Neurol. 2004;11:800-810.

5. Coeytaux A, Jallon P, Galobardes B, Morabia A. Incidence of status epilepticus in French-speaking Switzerland (EPISTAR). Neurology. 2000;55:693-697.

6. Chin RF, Neville BG, Peckham C, Bedford H, Wade A, Scott RC. Incidence, cause, and short-term outcome of convulsive status epilepticus in childhood: prospective population-based study. Lancet. 2006;368:222-229.

7. Mpimbaza A, Staedke SG, Ndeezi G, Byarugaba J, Rosenthal PJ. Predictors of anti-convulsant treatment failure in children presenting with malaria and prolonged seizures in Kampala, Uganda. Malar J. 2009;8:145.

8. National Institute for Clinical Excellence. The epilepsies: the diagnosis and management of the epilepsies in adults and children in primary and secondary care. Clinical guidelines, CG137 - issued Jan 2012. Available from: http://www.guidance.nice.org.uk/CG137. Accessed November 19, 2012.

9. Scott RC, Besag FM, Neville BG. Buccal midazolam and rectal diazepam for treatment of prolonged seizures in childhood and adolescence: a randomised trial. Lancet. 1999;353:623-626.

10. Johnson JB, Gross JF, Hale E. Effects of sublingual administration of nitroglycerin on pulmonary-artery pressure in patients with failure of the left ventricle. N Engl J Med. 1957;257:1114-1117.

11. Patel VF, Liu F, Brown MB. Advances in oral transmucosal drug delivery. J Control Release. 2011;153:106-116.

12. Anderson GD, Saneto RP. Current oral and non-oral routes of antiepileptic drug delivery. Adv Drug Deliv Rev. 2012;64:911-918.

13. Mancuso CE, Tanzi ME, Gabay M. Paradoxical reactions to benzodiazepines: literature review and treatment options. Pharmacotherapy. 2004;24:1177-1185.

14. Loftsson T, Gudmundsdottir JF, Sigurjonsdottir JF, et al. Cyclcodextrin solubilisation of benzodiazepines: Formulation of midazolam nasal spray. Int J Pharm. 2001;212:29-40.

15. Olkkola KT, Ahonen J. Midazolam and other benzodiazepines. Handb Exp Pharmacol. 2008;182:335-360.
16. Scott RC, Besag FM, Boyd SG, Berry D, Neville BG. Buccal absorption of midazolam: pharmacokinetics and EEG pharmacodynamics. Epilepsia. 1998;39:290-294.

17. Schwagmeier R, Alincic S, Streibel HW. Midazolam pharmacokinetics following intravenous and buccal administration. Br J Clin Pharmacol. 1998;46:203-206.

18. Muchohi SN, Kokwaro GO, Ogutu BR, Edwards G, Ward SA, Newton CR. Pharmacokinetics and clinical efficacy of midazolam in children with severe malaria and convulsions. Br J Clin Pharmcol. 2008;66:529-538.

19. Greenblatt DJ, Divoli M, Harmatz JS, Shader RI. Pharmacokinetic comparison of sublingual lorazepam with intravenous, intramuscular, and oral lorazepam. J Pharm Sci. 1982;71:248-252.

20. Anderson M, Tambe P, Sammons H, Mulla H, Cole R, Choonara I. Pharmacokinetics of buccal and intranasal lorazepam in healthy adult volunteers. Eur J Clin Pharmacol. 2012;68:155-159.

21. McIntyre J, Robertson S, Norris E, et al. Safety and efficacy of buccal midazolam versus rectal diazepam for emergency treatment of seizures in children: a randomised controlled trial. Lancet. 2005;366: 205-210.

22. Baysun S, Aydin OF, Atmaca E, Gurer YK. A comparison of buccal midazolam and rectal diazepam for the acute treatment of seizures. Clin Pediatr (Phila). 2005;44:771-776.

23. Mpimbaza A, Ndeezi G, Staedke S, Rosenthal PJ, Byarugaba J. Comparison of buccal midazolam with rectal diazepam in the treatment of prolonged seizures in Ugandan children: a randomized clinical trial Pediatrics. 2008;121:e58-e64.

24. Talukdar B, Chakrabarty B. Efficacy of buccal midazolam compared to intravenous diazepam in controlling convulsions in children: a randomized controlled trial. Brain Dev. 2009;31:744-749.

25. Ashrafi MR, Khosroshahi N, Karimi P, et al. Efficacy and usability of buccal midazolam in controlling acute prolonged convulsive seizures in children. Eur J Paediatr Neurol. 2010;14:434-438.

26. Nakken KO, Lossius MI. Buccal midazolam or rectal diazepam for treatment of residential adult patients with serial seizures or status epilepticus. Acta Neurol Scand. 2011;124:99-103.

27. Hindley D, Jameson H. Buccal midazolam: is a test dose in hospital needed? Arch Dis Child. 2006;91:544-545.

28. Hussain N, Regan E, Gosalakkal J, Whitehouse WP. Use of buccal midazolam in children. Arch Dis Child. 2006;91:1041-1042.

29. Kutlu NO, Dogrul M, Yakinci C, Soylu H. Buccal midazolam for treatment of prolonged seizures in children. Brain Dev. 2003;25:275-278.

30. Melendez R, Batista D, Font D, et al. Prolonged convulsions treated with buccal midazolam in a setting of mentally retarded patients with refractory epilepsy. Neurologia. 2006;21:411-413.

31. Kensche M, Sander JW, Sisodiya SM. Significant hypotension following buccal midazolam administration. BMJ Case Rep. 2010;15:2010.

32. NHS National Reporting and Learning System. Prevention of Harm with Buccal Midazolam. Available from: http://www.nrls.npsa.nhs. uk/resources/?EntryId45=132975. Accessed November 19, 2012.

33. Wilson MT, Macleod S, O'Regan ME. Nasal/buccal midazolam use in the community. Arch Dis Child. 2004;89:50-51.

34. European Medicines Agency. Buccolam (Midazolam). Available from: http://www.ema.europa.eu/ema/index.jsp?curl=pages/medicines human/medicines/002267/human_med_001479.jsp\&mid=WC0b0 $1 \mathrm{ac} 058001 \mathrm{~d} 124 \&$ murl=menus/medicines/medicines.jsp. Accessed November 19, 2012.

35. Joint Formulary Committee. British National Formulary for Children (online) London: BMJ Group and Pharmaceutical Press. Available from: http://www.medicinescomplete.com. Accessed November 19, 2012. 


\section{Publish your work in this journal}

Patient Preference and Adherence is an international, peer-reviewed, open access journal focusing on the growing importance of patient preference and adherence throughout the therapeutic continuum. Patient satisfaction, acceptability, quality of life, compliance, persistence and their role in developing new therapeutic modalities and compounds to

optimize clinical outcomes for existing disease states are major areas of interest. This journal has been accepted for indexing on PubMed Central. The manuscript management system is completely online and includes a very quick and fair peer-review system. Visit http://www.dovepress.com/ testimonials.php to read real quotes from published authors.

Submit your manuscript here: http://www.dovepress.com/patient-preference-and-adherence-journal 